Article

\title{
RE-DEFINING GOVERNANCE TO ADDRESS SOCIO-ECONOMIC INEQUALITY IN THE PHILIPPINES $^{1}$
}

Teresa S. Encarnacion Tadem*

DOI 10.24833/2073-8420-2019-3-52-10-22

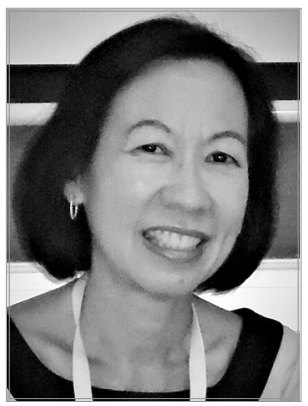

Introduction. The article is devoted to political and socio-economic processes in the Philippines in the context of re-defining and re-understanding of the "Good Governance" concept.

The term "good governance" in the Philippines is generally defined politically. As noted by the University of the Philippines Diliman National College of Public Administration and Governance (UP NCPAG), "good governance" is mainly concerned with improving the quality of government (QOG) which it perceives plays a key role in reclaiming democratic space. Thus, the main thrust is "to address the issues of anti-corruption, ethical public service service, efficient and effective delivery of public services by concerned Philippine institutions" (Forum Concept of the CLCD2018).

Material and methods. To address meaningful governance for UP NCPAG therefore is to assess the country's democratic institutions. This all leads to the major aims to assess the country's democratic institutions and whether democracy has led to meaningful governance reforms in the Philippine context. This definition of governance has generally characterized the assessment of the post-martial law administrations of Corazon C. Aquino (1986-1992), Fidel V. Ramos (1992-1998), Joseph E. Estrada (1998-2001), Gloria Macapagal-Arroyo (2001-2010), Benigno S. Aquino (2010-2016) and Rodrigo R. Duterte (2016- present).

Results. Although political reforms to strengthen the quality of government is indeed pertinent, this paper will, however, argue that these political reforms will only have a substantive impact on the democratization process in the country if it is coupled with policy reforms which address the growing socio-economic inequalities in Philippine society. In particular, there is a need for socio-economic policies which will address redistribution. Without this, not only will the economic but also the political gap between the rich and the poor remain wide, but it will also make the implementation of political reforms close to impossible.

Discussion and Conclusions. The first part of this paper will, therefore, define how the term "governance" has generally been applied to the Philippines. It will elucidate how its definition has been generally limited to the political sphere and why there is a need to expand on this to include the socio-economic domain. It will highlight this concern in the post-martial law administrations. The second part, on the other hand, will elaborate on this issue in the current Duterte administration.

\footnotetext{
* Teresa S. Encarnacion Tadem, Ph.D., Professor of Political Science, College of Social Sciences and Philosophy, Executive Director, Center for Integrative and Development Studies, University of the Philippines Diliman. e-mail: teresatadem@gmail.com

ORCID ID: 0000-0003-0397-2932

${ }^{1}$ Paper presented at the International Political Science Association (IPSA) Joint Coloquim of Research Committees 14, 28, 50 and 13 "Diversity and Democratic Governance: Legacies of the Past, Present Challenges and Future Directions?" University of Sarajevo, Bosnia-Herzegovina, 12-15 June 2018.
} 


\section{Introduction}

$\mathrm{T}$ The political definition of governance is generally derived from its association with government's primary role. There is thus the need to strengthen government institutions to make these effective instruments in implementing political and socio-economic policies. The major concern in developing societies, like the Philippines, is the issue of corruption which impedes the efficient fulfillment of government programs.

"Governance, however, is also a broader term than govenrment", whereby government is seen as only one of the institutions involved in governance. It is therefore possible to have "governance wtihout government" [16. P. 74]. Furthermore, the wider use of the term "reflects the blurring of the state/society distinction, resulting from changes such as the development of new forms of public management and the growth of public-private partnerships" [16. P. 74]. The involvement of the private sector through partnership with the state is understandable given the growing complexities of society whereby the state cannot do it alone. This definition however sees the state as class "neutral" and for private partnerships, it assumes a level playing field.

Governance and the neo-liberal development paradigm. For advocates of the neo-liberal development paradigm, the term governance is compatible with what it is advocating for, that is, development which emphasizes on the role of the market, liberalization and/or free trade, deregulation, and privatization. Thus, for the business community, the major concern is "economic governance" which like "political governance" is concerned with levelling the playing field and strengthening institutions for the efficient and unimpeded implementation of economic policies. It is also generally concerned with regulating competition among members of the business community. The major role of the state is thus regulatory. The mantra therefore is lesser government and more private sector.

A basic limitation of these perspectives of governance is the assumption that everyone can participate if the rules are followed and implemented. But even if this is the case, not everyone can join because only those with the means can do so. In other words, in societies like the Philippines, which is marred by wide socio-economic inequalities, only a few can partake in society's political and economic activities. There is a need therefore to widen the definition of governance to include the socioeconomic policies which are redistributive and empowering and which thus also address the problems of the basic sectors. This is not only in terms of how growth will be distributed across class but also along sectors, for instance women and the indigenous peoples. In other words, political reforms will only be mere palliatives or bandaid solutions to consolidating democracy in the country if it is not coupled with socioeconomic policies which will address growing class discrepancies. However, one of the most important political tendencies of our time is a certain strengthening of authoritarian elements in the political regimes of the world [47. P. 98]. This trend is not global so far, but it is important to understand how local specificity affects the processes of democratization.

Bad governance and exclusive growth. The argument for good governance as the panacea to addressing poverty was illuminated during the martial law period, whereby the Philippines was the basketcase of the Southeast Asian region. This was, however, not blamed on the economic policies which were perpetuated by the International Monetary Fund (IMF) and the World Bank but on the corruption of the Marcos dictatorship. Thus, there was no economic growth to address the country's poverty and underdevelopment. Fast-forward to the postmartial law period, and one would see that the country continually enjoys a high economic growth rate, as high as 6\% to 7\%. "In 2017, the Philippines' 6.7 percent full-year GDP growth remains one of the fastest in the region, after China's 6.9 percent and Vietnam's 6.8 percent" [30]. This was validated by the World Bank in its June "Global Economic Prospects 2020" report which stated that the Philippines "will remain as one of the fastest-growing countries in East Asia" at 6.6 per cent [23]. But there is still massive poverty and the further widening gap between the rich and the poor. Furthermore, there is still unabated rampant corruption.

Such a growth is also attributed not mainly to neo-liberal economic policies but to Overseas Filipino Workers or OFW remittances which, according to the Bangko Sentral ng Pilipinas, (Central Bank of the Philippines) in 2017 totalled to USD28 billion [10]. As of July 2018, OFW remittances totalled to USD2.7 billion. This is "higher by 4.5 percent compared to the level posted in the same month in 2017" [19].

Deprived of job opportunities in the country which can afford them a decent living, OFWs are forced to go abroad to seek greener pastures. This is because the high economic growth in the country is also jobless growth. Joblessness is mainly found in the agriculture and manufacturing, sectors where one finds the 
vast majority of unemployed Filipino people. Instead, the country has the growth of the service sector in the form of the business process outsourcing (BPO) companies, which mainly consist of call centers; hotels and malls, as well as property development, catering generally to the needs of the upper- and middle-classes of the Philippines. The popular usage of good governance does not address this concern.

Without addressing socio-economic inequalities, political reforms in the country will fall short of addressing the power structure which currently defines Philippine society. "There is no checks and balance and does not bring forth a competitive environment. In other words, society is no longer democratic" [43]. The argument therefore is good governance is impossible if socio-economic inequality is not adequately addressed.

The reality of the socio-economic inequalities which exists in Philippine society today is further mirrored in the latest 2017 Forbes Richest Filipino survey, which showed that:

The top 50 richest Filipinos in 2016, have a total wealth of USD304.8 billion. This is approximately $25 \%$ of the country's GDP. The top 10 richest Filipinos already constitute $17 \%$ of the GDP of $\$ 53$ billion. This is in stark contrast to $24 \%$ of the Filipino people who are rated below the poverty line according to a 2017 Social Weather Station survey. Moreover, $50 \%$ of the according to this SWS survey $50 \%$ of the Filipino people rated themselves poor [5].

Furthermore, the Wealth Report by Rick Santos head of the global consultancy firm Knight Franck, stated that there will be more "ultrarich" people in the Philippines, "growing at a rate considered the second highest inthe world, these are people "with at least $\$ 50$ million (P2.6 billion) in net assets." Calling them ultra high net worth individuals (UHNWIs), the Wealth Report 2018 stated that there will be 570 UHNWIs in 2022 an 84\% increase from the 310 UHNWIs in 2017. Their wealth is attributed mainly from the real estate industry and strong macroeconomic fundamentals" [5].

The global trend in socio-economic inequalites. This Philippine reality is also mirrored globally. Last month, the UN Conference on Trade and Development Agency (UNCTAD) said the world must ditch austerity and economic neoliberalism and undertake a global "New Deal" to rebalance the global economy and achieve prosperity for all [42]. Such a call is given more credence by a paper in May of 2016 by senior economists at the IMF which pointed out that "some neoliberal policies had increased inequality and were now jeopardizing durable global growth". Coming from the IMF, this call is ironic given that for 40 years, thisi nternational financial institution (IFI) "has driven economic liberalization of global economies" [42]. This brings forth the issue of global economic governance. The triumvirate which has dictated the global development trend and which has impinged on local economies are the IMF, the World Bank (WB), and the World Trade Organization (WTO).

Unlike the IMF and the WB, which were established in the 1940s, the WTO was founded in 1985. The IMF "was set up to oversee the global rules governing money in general and, in particular, to maintain currency stability through a system of fixed exchange rates." Since 1971, the IMF has embraced a neoliberal economic model, and requires countries to carry out stringent market-based reforms as a condition for receiving assistance" [16. P. 421].

Its partner in pushing forth this development paradigm is the World Bank, (formerly the International Bank for Reconstruction and Development) which was "designed to reduce the element of risk in foreign lending, thereby underpinning economic stability" [16.P. 421]. Since the 1980s, the Bank has geared its lending to 'structural adjustment', the reorientation of economies around market principles and their integration into the global economy" [16. P. 421]. And lastly, the WTO replaced the General Agreement on Trade and Tariff (GATT). Created by the Uruguay round of negotiations (198695), the WTO has wider and stronger powers than those of the GATT. "The WTO's mission is to 'liberalize' the world trade and create an 'open' global trading system" [16. P. 421].

For the IMF and the WB, their development mantra is to see economic growth in developing societies like the Philippines, but it is not concerned with addressing socio-economic inequalities within societies. This is the same for the WTO which mainly looks at itself as the gatekeeper of global governance, i.e., trading rules are followed and implemented by the member countries. It is not concerned with whether the effect of these trading rules are redistributive among and within countries.

The result of this type of economic governance has been dismal. As noted, "Four out of every five dollars of wealth generated in 2017 ended up in the pockets of the richest 1 percent, while the poorest half of humanity got nothing," [42]. Furthermore, "Oxfam found that 3.7 billion people, who make up the poorest half of the world, saw no increase in their wealth in 2017, while $82 \%$ of the wealth generated last year went to the richest 1 percent of the 
global population. The few at the top get richer and richer and the millions of the bottom are trapped in poverty wages" [42].

This global trend in socio-economic inequalities was further exemplifed by the Oxfam report, titled "Reward Work, not Wealth," which used data from Credit Suisse to compare the returns of top executives and shareholders to that of ordinary wokers. "The report found that chief executives of the top five global fashion brands made in just four days what garment workers in Bangladesh earned over a lifetime" [42]. It also noted that "the number of billionaires rose at a rate of every two days between March 2016 and March 2017, while in the United States the three richest people owned the same wealth as the poorest half of the population" [42].

\section{Results}

The Post-Martial Law Period and the Limitations of "Good Governance"

The underpinnings of these current local and global realities have manifested themselves during the post-martial law period (1986 to the present) whereby socio-economic policies have not addressed socio-economic inequalities making "good governance" possible. This can be seen in the experiences of the post-martial law administations.

Restoring Democracy Without Economic Redistribution: Corazon Aquino Administration (1986-1992)

Although the term "good governance" was not yet popularly used during the 1986 People Power Revolution, an important message concerning the overthrow of the Marcos dictatorship was that dictatorships are synonymous with corruption. And with corruption, one cannot attain the economic growth neededfor development. What further aggravated the situation was the repression during the martial law period of any form of opposition. All these spelled for "bad governance".

Thus, the problem was political, that is, the leadership. The Corazon Aquino administration, therefore, pursued the same neo-liberal economic policies, as espoused by the IMF/ World Bank, which were pursued by the Marcos dictatorship. There was, however, the hope that socio-economic inequalities would be addressed as President Aquino bannered her Comprehensive Agrarian Reform Program (CARP), as the cornerstone of her administration. CARP, however, was a very much watered down law. It also did not help that Aquino's cabinet "came from the conservative ruling class consisting of big-business class, political clans and landowning elites" [40. P. 47]. The CARP even allowed Aquino's very own Cojuangco family's Hacienda Luisita to be exempted.

Although democracy and political instability were restored under her administration albeit the eight attempted coup d'etats, the Filipino people did not seem to fully appreciate this as seen in the 1992 elections whereby Aquino's presidential candidate, Fidel V. Ramos, only received around $24 \%$ of the electoral votes. Ramos only won by a slim margin of a little just over $2 \%$ against his closest presidential candidate Miriam Defensor-Santiago. In other words, the assumed positive change of political leadership and regime did not seem to impact on the vast majority of the Filipino people.

The Era of Globalization and High Economic Growth Rate: The Ramos Administration (1992-1998)

The presidency of Fidel V. Ramos from 1992-1998 came at a time when the Asian region was booming by the early 1990s overcoming the crises of the 1980s. This yielded an unprecedented $7 \%$ economic growth rate in the Philippines. This was also attributed to Ramos' pursuit of a liberalization program which led to the privatization of profitable government enterprises and basic services such as water and electricity. He also dismantled the Aquino'a maternal family, the Cojuangco's monopoly of the Philippine Long-Distance Telephone Company (PLDT) and opened up the telecommunications industry".

Liberalization was, however, criticized, for failing to resolve a fundamental problem - the growing gap between a small, wealthy elite and the majority poor, both within the Philippines and internationally. The growing severity of public criticism against globalization compelled governments like that of the Philippines to commit themselves to resolving the imbalance and confronting its many consequences, the foremostst of which was the continuing widespread poverty.

Ramos, threfore, launched his Social Reform Agenda (SRA) as the anti-poverty program aimed at addressing socio-economic inequity. The latter part of Ramos' presidential term also brought forth the question of the sustainability of such economic growth in light of the 1997 Asian financial crisis. The neo-liberal policies of liberalization and deregulation made the Asian economies vulnerable to external factors.

As for the privatization efforts, a major tenet of the neoliberal develoment mantra, despite the privatization of the energy sector, the Philippines continues to have the highest 
electricity rates in Southeast Asia. Moreover, in the telecommunications industry, one has witnessed the emergence of a duopoly between GLOBE and SMART/PLDT telecommunications company. The country, also continues to suffer from the slowest internet service in the region. As noted, "Filipinos still lagged behind most regional neighbors and the global average in terms of internet speed [4].

Addressing the Class Issue: The Estrada Administration (1998-2001)

High growth rates without socio-economic redistribution led to the demise of Ramos' presidential candidate Jose de Venecia to Joseph "Erap" Estrada "who won the presidency by the largest margin of victory in postwar history on a populist platform depicting him as a friend of the masses". Estrada's "Erap para sa Mahihirap" (Erap for the poor) touched a chord among Filipinos living below the poverty line". This was despite the fact that the Catholic Church openly campagined against voting for a presidential candidate who was an "alcoholic, gambler and womanizer" in other words, all the ingredients for "bad governance." But the majority of the population could not care as their major concern, was the economic and not the political.

Estrada's economic managers, however, generally pursued the same neo-liberal development paradigm. Despite his popularity, exposés of corruption and crony capitalism led to his impeachment by Congress and ouster in a popular uprising dubbed as People Power 2 or EDSA II. This prompted his followers and members of the lower classes to come out in protest and attempt to stage a People Power III or EDSA 3 to restore Estrada back to power. The class divide was mirrored in EDSA 2 and EDSA 3 where the former was viewed as a middle-class uprising as in the 1986 People Power Revolution, while the latter was viewed as the protest of the masses. This prompted former President Corazon Aquino to say in a speech she delivered before the business community in the aftermath of the overthrow of Estrada that the EDSA III revolt is a "testament to the failure of the Philippine elite to share their wealth with the poor" [39. P. 147].

The Paradox of Massive Corruption and High Growth Rates: The Arroyo Administration: 2001-2010

The ascendance of Arroyo to the presidency was controversial because of the manner in which she came into power via a People Power revolt against a constitutionally elected president. Her legitimacy was further questioned three years later when she was perceived to have cheated in the 2004 presidential elections over her closest rival, the actor Fernando "FPJ" Poe Jr., a very close friend of Estrada. This therefore brought forth a crisis of leadership "whereby 8 out of 10 Filipinos wanted Arroyo out of Malacanang even before she completed her six-year term" [39. P. 147]. Issues of corruption involving the First Gentleman Mike Arroyo and his cronies led to the mass resignation of ten of her technocrats, that is, 7 Cabinet Secretaries and 3 Bureau Directors. This was the first ever in Philippine history [7].

Despite corruption scandals, the Philippines experienced high growth rates during President Arroyo's term. This however did not address the persistent wide gap between the rich and the poor. As a Social Weather Station (SWS) survey revealed, over-all hunger remained at a record-high 19 percent in November 2006. Moreover, more "than one in every two adult Filipinos (54 percent) felt that their quality of life is worse than their situation.... The National Economic Development Agency (NEDA) acknowledged that economic benefits have yet to reach the poor" [39. P. 151].

"Daang Matuwid" and Socio-Economic Inequality Amidst High Growth Rates: Benigno B.S. Aquino Administration (2010 to 2016)

The presidential candidacy of Benigno Aquino came at a time when his mother passed away in December 2009. As a democracy icon, she brought back memories again of why people came out in People Power I against corruption. This resonated with the electorate as surveys showed that the public saw President Arroyo as more corrupt than the dictator Marcos. Aquino won $42.08 \%$ of the votes in the 2010 presidential race. His stiffest opponent was Estrada, who got $26.20 \%$. Arroyo's presidential candidate, Gilbert Teodoro, a cousin of Aquino, was a cellar dweller. This was a testimony that the public did not like the corruption under Arroyo's administration. This was despite the high growth rates, but as with the pattern before of no socioeconomic redistribution. The Aquino administration thus got off on a good start. Politically, the president was popular, even getting as high as a $60 \%$ positive popularity rating in the first quarter of his presidency.

Economically the country was also doing well as seen two years later when "the World Economic Forum (WEF) released on September 5, its global competitiveness report which showed that the Philippines leaped by 10 notches to the 65th spot among 144 countries surveyed" [37. P. 117]. This ranking put the Philippines at the upper half of surveyed countries for the first time. 
But already in the first half of Aquino's term as president, there were already warning bells that the administration's economic policies should not only bring about growth but also address the redistributive aspects of development. During the last quarter of the Aquino administration, a survey was done on June 24-27 which found that " 15.2 percent of 1,200 respondents nationwide said that they suffered from involuntary hunger at least once in the last three months" [17]. "The latest figure was up from 13.7 percent in April 2017 during which 3.1 million families suffered from involuntary hunger" [17]. As with the previous post-martial law administrations, the Aquino administration was marked with high but exclusive growth rates.

The Lower-Class and the Duterte Administration's (2016 - present) Drug War and Neoliberal Policies

The result of this was the overwhelming support for the 2016 presidential candidacy of Rodrigo Duterte who won the presidential elections with a 6.62 million lead over the Aquino administration-backed runner-up, Manuel "Mar" Roxas [18]. Banking on his reputation as the Davao mayor who made the province safe and livable, foremost by getting rid of drugs, Duterte campaigned on the issue of good governance, that is, the fight against corruption and drugs. His campaign, however, also touched on the issue of the need for inclusive growth. That is, how Mindanao, which is the richest region in the Philippines is also the poorest economically with the poorest provinces being in the Autonomous Region of Muslim Mindanao or ARMM areas. This resounded well not only with the Mindanawans, both rich and poor, but also in the Visayas, a region which also speaks Bisaya, the same language as the Mindanawans and Duterte. The fight thus was against "Imperial Manila." Much, however, still remains to be seen if President Duterte is able to fulfill his campaign promise of a drug-free and corruption-free Philippine society and to address the poverty and socio-economic inequalities in Mindanao and the Visayas.

Duterte also initially appointed Cabinet secretaries which spanned the ideological spectrum of Philippine society. He appointed economic managers who espoused the neo-liberal policies of their predecessors which stressed privatization, deregulation, and market liberalization. This was most welcomed by both the local and foreign business commuities. These economic managers headed mainly the Secretaries of Finance (DoF), Trade and Industry (DTI), Budget and Management (DBM) and the National Economic Development Authority
(NEDA). This was most welcomed by both local and foreign business communities. For the lower classes, the appointment of key personalities identified with the Philippine Left, including the Communist Party of the Philippines (CPP) such as Rafael Mariano, a peasant leader, Judy Taguiwalo, a University of the Philippines Professor, and Liza Maza former Bayan Muna Party list representative as Secretaries of Agrarian Reform and Social Work and Development and Chair of the National Anti-Poverty Commission. Mariano was the first ever peasant appointed to a Cabinet position. He was formerly head of the Kilusang Mambubukid ng Pilipinas (KMP) or Movement of Farmers in the Philippines. Mariano was also formerly a House of Representatives member under the party-list party Anakpawis which is identified with the mainstream Left.

A couple of years into the Duterte administration, however, and the power balance has tilted in favor of the elite "haves" to the detriment of the "have nots". This can be seen in the following instances:

The drug war as anti-poor. In general, the Duterte administration's drug war has brought about condemnation from the international community. In August 2017, Agnes Callamard, a special rapporteur on summary executions of the United Nations raised the alarm bells which has resulted in more than 3,900 killings by the Philippine National Police [42]. Presidential Spokesperson Harry Roque call Callamard an impartial rapporteur while President Duterte declared Callamard as persona non grata. Aggravating this situation is that the victims of the Duterte Administration's drug war have also generally been from the lower classes. Such an accusation came to light when the Department of Justice (DOJ) prosecutors dismissed the cases against high-profile drug suspects Peter Lim, Kerwin Espinosa and Peter Co. The decision of the DOJ, which was headed then by President Duterte's trusted aide, Secretary Vitaliano Aguirre II, "drew criticism and outrage, along [with] accusations that the government was only targeting the small players in the drug war and letting the big fish get away" [33].

The fate of left-wing personalities in the Cabinet. The appointment of leftist personalities in his Cabinet was not surprising as President Duterte styles himself as a "socialist" and has close associations with members of the CPP, foremost of whom is CPP founder Jose Ma. Sison. He also has close advisers who were former CPP members, e.g., Leoncio Evasco. While at the helm of DAR, Mariano called for a twoyear moratorium on land conversions which 
was actually supported by President Duterte. This was strongly opposed by Duterte's National Economic and Development Authority (NEDA) Director-General Ernesto Pernia who believed that such a policy will not be good for foreign investors and the real estate sector. Pernia's position has been backed by the business community, in particular, the Chamber of Real Estate and Builder's Association (CREBA) [38].

Duterte, however, left it to the landlorddominated Philippine Congress on whether his left-wing Cabinet members would get their confirmation or not of its Comission on Appointments. Not surprisingly, Mariano and Taguiwalo did not gain the approval of the Commission. As for Liza Maza, her NAPC government position did not warrant the approval of Congress' Commission on Appointments. NAPC, however, remains to be a marginalized anti-poverty government agency and its head Liza Masa ultimately resigned.The determination of what socio-economic policies are to be pursued continue to lie mainly with the government's economic managers.

\section{The Failure to End "Endo"}

It is not surprising therefore that despite his campaign promise to pursue pro-poor economic policies, this has not been a reality. Foremost of this is the failure to end "endo", the end to contractualization. This was supposedly a cornerston of the Duterte administration's economic policy. "Endo" is the practice of "hiring employees for five months to circumvent labor laws providing them benefits and job security" [35]. "The practice is also referred to as contractualization. Durterte has even threatened to kill" businessmen engaged in this illegal practice" [35].

On May 1, 2018, President Duterte signed Executive Order (EO) No. 51 prohibiting contractualization, or endo. "Section 2 of the EO bans 'illegal contracting and subcontracting' when undertaken to circumvent workers' right to security of tenure, self-organizations and collective bargaining, and peaceful concerted activities" [3]. "Labor Secretary Silvestre Bello III told reporters that other forms of contractualization - like seasonal or project-based jobs of janitors and maintenance workers that can be outsourced - were still permitted" [3].

"According to the Article 281 of the Labor Code, probationary employment shall not exceed six months from the date the employee started working, unless it is covered by apprenticeship agreement stipulating a longer period" [20].

The same article also stated: "An employee who is allowed to work after a probationary period shall be considered a regular employee" [20].

The Employers Confederation of the Philippines (ECOP) said that "they will live with it and comply" despite the fact that they expressed fear that the security of tenure is "too loose and might be abused" [31]. The business groups also reiterated that contractualization or "endo" is the business model all over the world. Such a practice it pointed out brings forth flexibility in work arrangements which is the global practice. The business community's position was supported by the American Chamber of Commers of the Philippines (AmCham) [5].

But the labor groups led by Nagkaisa together with the militant group Kilusang Mayo Uno and the Trade Union Congress of the Philippines, rejected it, calling the EO the version which was opposed by labor groups. This was because this EO did not define the security of tenure (SOT) as the direct relationship between principal and a worker [31]. Renato Magtubo, the Nagkaisa spokesman and Chairman of the Partido Manggagawa, pointed out that "without their SOT definition, a contractual arrangement will still be considered legal if workers are regularized by his or her contractor, instead of their principal employer" [31].

As further expounded by Jose Sony G. Matula, president of the Federation of Free Workers (FFW), "the main point of the labor-proposed EO was the assurance that the security of tenure of the worker who have been working on different companies must be respected by directly hiring them as stipulated in the Philippine Constitution, Labor Code of the Philippines and different Supreme Court jurisprudence on labor issues" [21].

At the 16th Labor Executive Updates organized by the Employers Confederation of the Philippines (ECOP)... "business groups were one in saying that abolishing contract work would mean dire consequences, not only to employers and their businesses but also to the national economy, the country's competitiveness and to Filipino workers who search for decent and quality jobs" [20]. Furthermore, Trade Secretary Ramon Lopez and the business groups warned that "making direct hiring the norm for employment would scare off investors" [5]. A little over a year later, President Duterte broke his election promise and vetoed the security of tenure bill [1]. Act

The Adverse Reperucssions of the TRAIN

Another anti-poor policy which is associated with the Duterte administration was the recent passing of the Tax Reform for Acceleration 
and Inclusion (TRAIN) also known as Republic Act No. 10963. This is the first package of the Comprehensive Tax Reform Program (CTRP). For the Freedom for Economic Foundation (FEF), an advocacy group for good economic governance and market friendly reforms, the tax reforms were deemed as a "forward-looking" fiscal program [15]. The effect of the population though has not been as positive and the TRAIN Act is viewed as anti-poor because of the following reasons:

Implemented in January 2018, the TRAIN ACT brought about the increase in the prices of basic commodities to 4.3 percent in March 2018 [29]. As noted by the Philippine Statistic Authority (PSA), the TRAIN ACT added to the inflation rate which was much faster than the inflation rate of 3.1 percent during the same period last year [29]. The inflation was generally attributed to the higher prices of "cigarettes and alcoholic drinks" (de Vera 2018, B1). Due to the TRAIN law which "jacked up or slapped new excise taxes on cigarettes, sugary drinks, oil products, vehicles and others to compensate for the restructured perrsonal income tax regime that raised the tax-exempt cap to an annual salary of P250,000" [11]. The biggest fear is the additional pressure on inflation that is expected to come from rice [27]. In July 2018, the inflation went up to $5.7 \%$ which was considered the fastest rise in over five years [13]. By August 2018, inflation soared at $6.4 \%$. This was considered a nine-year high [13].

Decline of purchasing power. "Alan Tanjusay, spokesperson for the Associated Labor Unions-Trade Union Congress of the Philippines (ALU-TUCP) said "the purchasing power of the minimum wage earners also dropped across the country as prices of goods and services went up from January to April 2018" [34]. He added that "informal sector workers would be worse off under the TRAIN ACT because they would be made to pay more for goods and services withouth earning extra from adjusted income tax exemptions" [34].

Workers' lay-off. But a worse scenario is that labor groups expect more workers to be laid off due to TRAIN ACT because "it jacked up or slapped new excise taxes on goods like oil, cigarettes, sugary drink..." As a result of this, labor groups believe that companies which produce these commodities like Coke, for example, will use this as an excuse to downsize their manpower as a result of corporate restructuring [34].
Higher tax burden on the poor. The leftwing Makabayan bloc $^{2}$ in the House of Representatives, pointed out that while the TRAIN ACT "provides higher income tax exemption for those earning below P250,000 annually, it actually levies higher tax burden to the poor majority with the removal of some VAT exemptions and introduction of new excise taxes on petroleum products and sugar-sweetneed beverages" [9].

The complaints of the Makabayan bloc was validated by the University of the Philippines School of Statistics Dean Dennis S. Mapa who "estimated that the poorest 30 percent of the population bore the brunt of the increases in prices" [24]. Duterte's economic managers cited external factors, "the spike in oil prices and weakening of the peso, as the principal causes for the inflation surge." It was, however, pointed out that if this is the case, "how come the country's Asean neighbors who were also subjected to the same conditions enjoy favorable inflation rates?" As noted in August, "Indonesia's inflation rate was 3.2 percent; Vietnam, 3.98\%; Malaysia, $0.9 \%$; Thailand, 1.6 per cent; and Singapore, 1.9 percent" [25].

Socio-economic Inequality Admidst the High Growth Rates. This situation comes at a time when the Philippine economy is said to be in a "golden age of growth." That is, the economy is currently enjoying a high growth rate of $7 \%$ to $8 \%$ and is performing its "best over the past nearly five decades" [24]. For National Economic and Development Authority (NEDA) Director-General and Socio-economic Planning Secretary Ernesto M. Pernia, this will allow the economy to provide more jobs and lift millions out of poverty [24]. A deja vu of the past which has still to be seen to come true. As noted, when the Philippine economy grew by $6.9 \%$ during the third quarter of 2017, making it one of the fastest in Asia, the agriculture sector's growth however slowed to 2.5 percent from 3 percent a year ago and $6.3 \%$ from the previous quarter [13]. This is quite significant as this is the poorest sector of the Philippine economy which consists of around 30 percent of the workforce.

But as pointed out by Akbayan Rep. Tom Villarin, while such the 6.9 percent growth "will have a boost to the market, [the] government has not addressed inequality, unemployment, lack of livelihoods and rising inflation that hits the poor most" [46]. As futher noted by Ifugao Rep. Teddy Baguilat Jr., "poverty and unemployment remained high despite the growing

\footnotetext{
2 Besides Bayan Muna, members of the Makabayan bloc include ACT Teaches, Anakpawis, Kabataan and Gabriela party-lists (Dela Cruz 2018, A4).
} 
economy" [46]. It also remains to be seen if this high growth economy will address the high poverty or hunger incidence in the country. On October 14, 2016, a survey by the Social Weather Stations (SWS) found that four in every Filipino families, equivalent to some 9.4 million households, rated themselves poor. The 42-percent self-rated poverty incident last September 2016, was considered a "record" low since the 43 percent logged in March 2010 (Pazzibugan et.al. 2016, A15). Furthermore, according to the SWS March 23-27, 2018 poll, joblessness in the country hit the highest level in five quarters in March. The "level of joblessnes was 23.9 percent, or an estimated 10.9 million, up from 15.7 percent, or 7.2 million, last December" [2].

As argued by FFW's Matula, "the economy is growing and expanding, but no trickle-down effect to the workers is felt because they have long been chained to contractual working arrangements" [21]. None other than Department of Finance (DOF) Undersecretary Karl Kendrick T. Chua, who is bannered as the World Bank poster boy for the conceptualization and implementation of TRAIN, noted that protest rallies and other public disturbances "are rooted not in poverty but in inequality." As he further notes, "It is for having divisive inequality for people to see that although they are not poor, many people, enjoy far more than they do. That is why they become destructive and engage in some form of violence" [22]. War

Linking Neo-liberalism with the Drug

Thus the neo-liberal economic policies of the Duterte administration, like the past Philippine administrations have spelled for "bad governance" and UN Special Rapporteur Callamard on October 18, 2017 has pointed out its severe political repercussios. Callamard in particular has blamed neoliberalism for unleashing violence worldwide, calling "the liberal vision for development" a killer in the community [42]. Callamard said "a one-size-fits-all model of economic development has exacerbated inequality and was a factor in the rising tide of arbitrary executions and extrajudicial murders" [42]. "The restructuring of economies and the liberal vision of development is trickling down to every community and is a killer, in many ways," Callmard told Thomson Reuters Foundation in Dublin [42].

Callamard joins a host of institutions that have called into question the limits of the liberal economic model, which has for 40 years dominated thought on economic development[42]. Yet she pointed out that "neoliberalism did not garner the same attention as political populism and brutal military-style policing, which were making huge headlines for instigating violence worldwide" [42].

\section{Absence of popular participation and con-} sultation.

The implementation of economic policies which are anti-poor is also blamed for the lack of popular participation and consultation with the stakeholders, a practice which has characterized the post-martial law administrations. This for many has spelled for "bad governance". According to the labor coalition Nagkaisa, they were taken for a ride by the Duterte Administration concerning the "endo" EO. They pointed out that "There was no consultation on our fifth draft submitted to the Office of the President on April 13. The EO was signed definitely for the employers and not the workers" [31]. As further clarified by Magtubo, what President Duterte signed was the EO drafted last November 2017 which used the "definition of security of tenure in the Labor Code. It does not have teeth. It is just similar to the Department Order (DO) $174^{3 \prime \prime}$ and this was the reason why the labor groups reject it [31].

The labor unions also pointed out that the Department of Trade and Industry (DTI) Executive Order (EO) proposal which the labor groups opposed does not address the contractualization problem. As pointed out by Rene Magtubo, chairman of Partido Manggawa (PM), "The DTI [EO] is obviously [based on] a business-as-usual policy that allows labor contracting on almost all jobs and functions that has changed the norm of employment from direct-hiring to agency-hiring" [21]. The EO of the labor unions is almost identical with that of the DTI and the employers' group "except for the definition of the right to security of tenure $(\mathrm{SOT})^{\prime \prime}$. In their version of the EO, labor groups, defined the SOT as the direct hiring relationship between the principal employer and the employee. The DTI and employers opposed this definition on the SOT since if applied, contracting and subcontracting of labor will be prohibited if they violate the worker's SOT. This, in effect, will make contractualization prohibited in general [20].

The labor leader made this assertion as he and other labor leaders who belong to the Nag-

\footnotetext{
${ }^{3}$ DO 174 was issued by by the DOLE in 2017 to further restrict the practice of contractualization. "The issuance was unamimously rejected by labor groups since it failed to prohibit contractualization" (Rosales and Medenilla 2018, A2).
} 
kaisa Labor Coalition were alarmed after Duterte canceled his meeting with them on Monday, April 16, "following the request of Trade Secretary Ramon M. Lopez. Lopez reportedly asked the President to postpone his meeting with the Nagkasia labor leaders because he was afraid that Duterte will approve the Nagkaisaproposed EO, which will eventually oblige businessmen to increase workers' daily wages [21]. This highlights the priority which the Duterte Administration gives to the business sector rather than the labor groups.

Social Exclusion and Inequality and the Rise of Right-wing Populist Governance

The Duterte administration's anti-poor economic policies as well as the failure to provide an environment of popular participation and consultation in the decision-making process for the marginalized sectors of society has further perpetuated a situation of social exclusion and inequality in the country. Such a conditon is viewed as having brought about the rise of a populist right-wing type of governance. This is a trend seen not only in the Philippines but also in other developing and developed countries. An example of the latter is the victory of Donald Trump in the 2017 U.S. elections. As for the Philippines, Supreme Court Justice Marvic Leonen has warned that "disenchantment of those whose voices remain unheard and stifled have led them to look for a false messiah" [14].

As Leonen further adds, "Demagogues - this [is] just a warning, I am not referring to anyone - can arise out of legal frames that are formally democratic," the magistrate said. "Usually they take advantage of the exclusion and frustration of the majority. They offer quick fixes and represent themselves sharply from the more conscientious leaders who know that the major problems require patience, strategy, and participative resources" he added [14].

This may explain why, despite his antipoor policies, President Duterte continues to enjoy excellent ratings. In January 2018, Pulse Asia Survey released its findings showing that last September 2017, President Duterte's approval and trust scores were both $80 \%$. "The President enjoyed majority approval (72 to 93 percent) and trust (74 to 94 percent) ratings across all geographic areas [18]. In particular, the survey found that 73 percent of respondents believed policemen or soliders committed EJKs - an increase from 67 percent in June 2017. Despite this, 88 percent supported the campaign against illegal drugs [18].

Three months later, in a Social Weather Stations (SWS) survey conducted from March 23 to 27,2018 , Durterte received a "very good" at +58 percent rating. This was despite a drop in his net satsifaction rating by 12 points [2]. In June 2018, President Duterte's trust rating “dropped to its lowest in the June survey taken since he took office in June 2016" according to a June 2018 Social Weather Stations Survey (SWS). He, however, still earned a net trust rating of very good +69 [33].

\section{Conclusion}

This paper thus argued that for good governance to adequately make positive and substantive inroads in the democratization process in the Philippines, there is a need for it to address not only the political, e.g., corruption but also the socio-economic aspects of development. The latter mainly refers to the need to confront the issue of wide socio-economic inequalities in society. To do this, there is a need to challenge the limitations of neo-liberalism which has always been the dominant development paradigm in the country. Such a development paradigm has brought forth high economic growth rates which have remained exclusive to the detriment of the vast majority. The Philippine situation is a microcosm of the global trend of exclusive growth.

The previous post-martial law administrations of Corazon Aquino, Ramos, Estrada, Macapagal-Arroyo, Benigno S. Aquino as well as the current Duterte administration all have highlighted the failure of good governance to deal with rising socio-economic inequalities. This was heightened during the era of globalization which marked the Ramos administration where one witnessed the 1997 Asian Financial Crisis (AFC). Globalization and the AFC intensified the class bias against the poor of the country's economic policies leading to the presidency of Estrada. The same neo-liberal economic policies, however, continued to be pursued not only by Estrada but also his predecessor President Macapagal-Arroyo under whose administration the country experienced high growth rates amidst accusations of massive corruption against the leadership. Worst of all was that it remained to be an exclusive growth. Such a trend continued under the Benigno S. Aquino administration minus the accusations of rampant corruption but nevertheless leading to the electoral presidential victory of President Duterte.

Under the Duterte administration, however, anti-poor economic policies such as the failure to end contractualization and high inflation rates brought about by the TRAIN ACT continued to exacerbate socio-inequality and 
poverty in the country. It also did not help that the anti-drug war, which catapulted President Duterte into power, is perceived to be targeting the poor. The current paradox, however, is President Duterte continues to enjoy a high popularity rating despite some minor declines. Some have pointed out that such a situation has reflected a global phenomenon of the rise of right-wing populist leaders in the desperation of the majority of the world's population who are excluded from the fruits of growth. In the Philippines, such an exclusion, however, continues to remain a reality and, like in the past, it may be a matter of time when the Filipino people will look for a new "messiah" or as warned by Senator Panfilo Lacson "when the stomach protests, prepare for revolution" (Yap and Nonato 2018, A18).

\section{References:}

1. Aurelio, J.M., 2019. Jeers, cheers as Du30 breaks vow to ened 'endo'. Philippine Daily Inquirer. July 27. A1 \& A7.

2. Aurelio, J.M., 2018. Joblessness Hits Record High. Philippine Daily Inquirer. May 2. 2018.

3. Bunachita, J.S., 2018. Duterte Signs EO on 'endo. Philippine Daily Inquirer, May 2, 2018.

4. Camus, M.R. n.d., 2017. PH is World Leader in Social Media Usage. Philippine Daily Inquirer.

5. Canivel, R.S.C., 2018. Ending 'Endo' Will Scare off Investors - DTI. Philippine Daily Inquirer, May 18, 2018.

6. Canivel, R.S.C., 2018. Ending 'endo' will scare off investors - DTI. Philippine Daily Inquirer. April 18, A2.

7. Contreras, V.O., Avendano, Ronnel W. Domingo and Christian V. Esguerra., 2005. "Ten key officials withdraw support. Philippine Daily Inquirer, July 9, A1 \& A2.

8. Cruz, N., 2013. Don't Vote for Members of Political Dynasties. Philippine Daily Inquirer, February 11.

9. Dela C., Jovee M.N., 2018. Business Mirror. May 11, A4.

10. De Vera, B.O., 2018. DOF: April Inflaion Likely Hit 4.5\%. Philippine Daily Inquirer, May 4.

11. De Vera, B.O., Ph. C. Tubeza, and Reuters and AP., 2018. Abuse or Unemployment: Stark Choice for Many Filipino Maids. Philippine Daily Inquirer.

12. De Vera, B. O., and Jovic Yee, 2018. Fuel, Food Costs Push Inflation Up to 5.7\%. Philippine Daily Inquirer. August 8.

13. De Vera, B. O., Jovic Yee, and Dexter Cabalza, 2018. Soaring Food Prices Fueled 6.4\% Inflation in August. Philippine Daily Inquirer, September 6.

14. Dizon, N., 2018. SC Justice Warns of Rise of 'False Messiahs.' Philippine Daily Inquirer, February 15, 2018.

15. Dumlao-Abadilla, D., 2018. 'Tax Reforms Winning It for Du30. Philippine Daily Inquirer, October 17, B2-1.

16. Heywood, A., 2013. Politics. New York: Palgrave MacMillan.

17. Inquirer Research. 2013. More Families Went Hungry, Survey Says. Philippine Daily Inquirer. August 16, A4.

18. Inquirer Research, Ph. C. Tubeza, Vince F. Nonato, and Jocelyn R. Uy., 2018. Poll: 8 out of 10 Pinoys Trust the Presidenet. Philippine Daily Inquirer, January 9.

19. Lucas, D. n.d. Filipino Overseas Workers' 7-Mo Dollar Remittances Hit \$18.5B. Philippine Daily Inquirer.

20. Medenilla, Samuel P., 2018. Duterte Again Opts to Avoid Inking Contractualization EO. Business World. Business World. April 16.

21. Nicolas, B.D., 2018. Duterte Seen Appeasing Labor with E.O. on May 1. Business World. April 17.

22. Ordinario, Cai U., 2018. PHL Still One of the Fastest-Growing Economies in E. Asia- World Bank. Business Mirror. June 7.

23. Ordinario, Cai U., 2018. Growth seen at 7\% to $8 \%$ as PHL economy enters 'goldilocks period.' Business Mirror. April 20.

24. Ordinario, Cai U., 2018. DOF official: Inequality, not poverty, is root of discontent. Business Mirror.

25. Palabrica, R.J., 2018. Annus Horribilis. Philippine Daily Inquirer, September 11, sec. Corporate \& Securities Info.

26. Pazzibugan, D.Z., Kate Pedroso, and Inquirer Research., 2016. 9.4M Households Rate Themselves Poor - SWS. Philippine Daily Inquirer. October 14.

27. Philippine Daily Inquirer. 2018. Inflation Fears, April 9, sec. Philippine Daily Inquirer (PDI) Editorial.

28. PDI. 2018. Richest 1 Percent Corner 82 Percent of Wealth Generated Globally. Philippine Daily Inquirer. January 2018.

29. PDI. 2018. Solgen: P200 Monthly Subsidey Will Protect Poor Families from Effects of TRAIN Law. Philippine Daily Inquirer. May 2, 2018.

30. Remo, Amy. 2018. ADB 51st Annual Meeting, Manila, May 3-6, 2018L Exciting Times in Asia, PH. Philippine Daily Inquirer. May 4. 2018.

31. Rosales, E.F. and Medenilla S.P., 2018. Ecop OK with 'endo' EO, but workers dissastisfied. Philippine Daily Inquirer. May 2.

32. Salaverria, L.B., 2018. Cabinet revamp? President set to fire underperformers. Philippine Daily Inquirer. March 17.

33. Salaverria, L.B., 2018. Though Down 8 pts, DU30 Keeps 'Very Good' Rating.' Philippine Daily Inquirer. 
34. Santos, T.G., 2018. Labor groups expect more workers to be laid off due to TRAIN Act. Philippine Daily Inquirer. April 30.

35. Sauler, E., 2016. Bello on end of 'endo': 16,000 workers regularized. Philippine Daily Inquirer. October 21.

36. Tadem, T.S.E., 2008. Situating NGO Advocacy Work in Middle Class Politics in the Philippines. In The Rise of the Middle Classes in Southeast Asia, edited by Shiraishi Takashi and Pasuk Phongpaichit. Kyoto: Kyoto University Press and Melbourne: TransPacific Press, P. 194-216.

37. Tadem, T.S.E., 2012. Philippine Technocracy as a Bulwark against Corruption: The Promise and the Pitfall. Philippine Social Sciences Review. January-June. P. 99-124.

38. Tadem, T.S.E., 2018. Chapter 20: Technocracy and Class Politics in Policy-making. In Thompson, Mark R. and Eric Vincent C. Batalla. Routledge Handbook of the Contemporary Philippines. London and New York: Routledge Taylor \& Francis, P. 262-272.

39. Tadem, T.S.E., 2008. The Perennial Drift to the Right: Transition to Democracy in the Philippines. In States of Democracy: Oligarchic Democracies and Asian Democratization, edited by Hee Yeon Cho, Lawrence Surendra, and Eunhong Park. Mumba: Earthworm Books, P. 136-162.

40. Tadem, T.S.E. and Tigno J.V., 2006. Chapter 3:"Philippine Social Movements after Martial Law" in Philippine Politics and Governance: Challenges to Democratization and Development, edited by T. S. E. Tadem and N. M. Morada. Quezon City: Department of Political Science, University of the Philippines, Diliman, P. 43-62.

41. The Inquirer Staff. 2018. Labor Groups Unhappy with Executive Order. Philippine Daily Inquirer. May 21.

42. Thomson Reuters Foundation. 2018. Neo-liberalism kills, says UN critic of drug war in PH. Philippine Daily Inquirer. October 20.

43. Tubeza, Ph.C., 2017. 'Fat' dynasties linked to worsening poverty. Philippine Daily Inquirer. February 16.

44. Philippine Daily Inquirer. 2018. Duterte's 'shoot in the vagina' remark hit. Philippine Daily Inquirer. February 12.

45. Yap, DJ., 2018. Wealth Didn't Trickle down to the poor, say DU30 Critics. Philippine Daily Inquirer. November 27.

46. Yap, DJ., 2018. Lacson Warns of Revolution if Price Increases Are Not Checked. Philippine Daily Inquirer. May 28.

47. Yarovova, T.V., Litvinova, T.N., 2017. Authoritarian revival in South Eastern Europe: origins and trends. Journal of Law and Administration. № 4. P. 97-102.

\section{ПЕРЕСМОТР ГОСУДАРСТВЕННОГО УПРАВЛЕНИЯ В ОТНОШЕНИИ СОЦИАЛЬНО-ЭКОНОМИЧЕСКОГО НЕРАВЕНСТВА НА ФИЛИППИНАХ}

Введение. Статья посвящена политическим и социально-экономическим процессам на Филиппинах $b$ контексте пересмотра и переосмысления кониепиии «Good Governance» («хоромее управление»).

Термин «хорошее управление» на Филиппинах обычно определяется политически. По мнению ученых Национального института государственного администрирования и управления Филиппинского университета в Дилимане (UP NCPAG), «хорошее управление», главным образом, связано с улучшением качества управления (QOG), которое играет ключевую роль в восстановлении демократического пространства. Таким образом, основная задача заключается $b$ «решении вопросов противодействия коррупиии, этики государственного управления, эффрективного и действенного предоставления государственных услуг заинтересованными филиппинскими учреждениями» (Кониелизя Форума CLCD2018).

Материалы и методы. Решение проблемы качества государственного управления связа- но с оиенкой демократических институтов страны, а также поиском ответа на вопрос, привела ли демократия к реальным реформам управления $b$ филиппинском контексте. Такое исследование предполагает оценку и сравнение государственного управления после отмены военного положения $b$ администрациях президентов Корасон Акино (1986-1992), Фиделя В. Рамоса (1992-1998), Джозефа Эстрада (19982001), Глории Макапагал-Арройо (2001-2010), Бенигно Акино (2010-2016) и Родриго Р. Дутерте (2016-настоящее время).

Результать. Хотя политические реформы, направленные на повышение качества государственного управления, действительно уместны, в этой статье доказано, что такие политические реформы окажут существенное влияние на процесс демократизации в стране только если они будут сопровождаться реформами, направленными на преодоление растущего экономического неравенства $b$ филиппинском обществе. В частности, существует необходимость в грамотной социально-экономической 
политике, которая будет направлена на перераспределение доходов. Без этого будет наблюдаться не только большой экономический, но и политический разрыв между богатыми и бедными, что также сделает практически невозможным проведение политических реформ.

Обсуждение и выводы. В первой части статьи показано, как термин «государственное управление» обычно понимается на Фимиппинах. Выясняется, что его определение $b$ основном касается политической сореры, поэтому необходимо расширить его понимание, чтобы включить и социально-экономический аспект. Эту проблему ярко демонстрируют

Ключевые слова: государственное управление, Филиппины, политические преобразования, социальноэкономические реформы. меры соииальной политики различных администраций после отмены военного положения на Филиппинах. Вторая часть работы более подробно освещзает, как ставится социальныи вопрос $b$ нынешней администрации президента Родриго Дутерте.

Тереза С. Энкарнасьон Тадем, доктор философии, профессор политологии, Колледж социальных наук и философии, исполнительный директор Центра интеграционных исследований и исследований развития, Филиппинский университет в Дилимане.

Keywords:

Good Governance, the Philippines, political transformation, socio-economic reforms. 